\title{
Prinsip-Prinsip Etika Kristiani Bermedia Sosial
}

\author{
Simon ${ }^{1}$ \\ Tan Lie Lie ${ }^{2}$ \\ Heppy Wenny Komaling3 \\ 123 Sekolah Tinggi Teologi Anugrah Indonesia \\ simonpetrus.45144@gmail.com, ${ }^{1}$ tlielie88@gmail.com, ${ }^{2}$ happywk076@gmail.com ${ }^{3}$
}

\begin{abstract}
Indonesian netizens are often labeled as social media users at will without heeding politeness when interacting. This assessment is further confirmed by a survey conducted by Microsoft, that Medsos users are labeled as netizens with the worst politeness level for Southeast Asia scale. The predicate is certainly aimed at allreligius netizens without emphasizing certain beliefs. The low politeness indicates the lack of social media ethics applied by the people of the country. Ironically, Indonesia is known as areligius and civilized country, it seems invisible ifyou look at the behavior of netizens who are. The method used in this paper is descriptive qualitative method with a literature study approach. The description of this topic religion certainly teaches how politeness and politeness in the public space are displayed especially in social media, because politeness is an indikator we are called ethical or not. The principle of Christian ethics teaches that when using social media what a believer must do is not to do body shaming with other online media users, or not to comment racistically. Because God does not differentiate between fellow humans by loving one and not loving another just because humans are different physically, race or nation. The next principle of Christian ethics in social media is not to argue theologically and not to spit negative things. The goal is to avoid quarrels, let alone hate speech.
\end{abstract}

Keywords: christian ethics; netizen; social media

\begin{abstract}
Abstrak
Netizen Indonesia kerap di cap sebagai pengguna media sosial sesuka hati tanpa mengindahkan kesantunan ketika berinteraksi. Penilaian ini makin dipertegas melalui survei yang dilakukan oleh Microsoft, bahwa pengguna Medsos dilabeli sebagai netizen dengan tingkat kesopanan paling buruk untuk skala Asia Tenggara. Predikat itu tentu ditujukan kepada semua netizen yang beragama tanpa menitik-beratkan keyakinan tertentu. Rendahnya kesopanan menandakan kurangnya etika bermedia sosial diterapkan oleh masyarakat tanah air. Ironisnya, Indonesia yang di kenal sebagai negara yang religius dan beradab, hal itu seakan tidak terlihat bila melihat perilaku netizen yang bar-bar. Metode yang digunakan dalam tulisan ini adalah metode kualitatif deskriftif dengan pendekatan studi kepustakaan. Uraian dari topik ini agama tentu mengajarkan bagaimana kesopanan dan kesantunan di ruang publik ditampilkan terlebih dalam bermedia sosial, karena kesopanan itu merupakan indikator kita di sebut beretika atau tidak. Prinsip etika Kristiani mengajarkan bahwa ketika bermedia sosial yang harus dilakukan orang Kristen adalah tidak melakukanbody shaming kesesama pengguna media online, maupun tidak berkomentar secara rasis. Karena Allah tidak membeda-bedakan sesama manusia dengan mengasihi yang satu dan tidak mengasihi yang lain hanya karena manusia itu berbeda secara fisik, ras atau bangsa. Prinsip etika Kristiani berikutnya dalam bermedia sosial adalah tidak berdebat secara teologis dan tidak mengumbar hal negatif. Tujuannya agar tidak terjadi pertengkaran apalagi ujaran kebencian.
\end{abstract}

Kata Kunci: etika kristiani; media sosial; netizen 


\section{Pendahuluan}

Pada bulan Februari 2021, Digital Civility Index (DCI) merilis laporan survei Microsoft yang mengukur bagaimana tingkat kesantunan atau kesopanan netizen dalam bermedia sosial secara global. Dari survei yang dilakukan, netizen Indonesia berada paling rendah untuk skala Asia Tenggara. Digital Civility mengklasifikan angka skala 0100, adalah rujukan dalam pengukuran. Angka yang paling rendah menunjukkan kesopanan yang baik, sedangkan angka yang tinggi mengindikasikan kesopanan rendah. Hasilnya, netizen Indonesia berada pada poin ke 76. Dengan tingginya angka tersebut, netizen Indonesia rendah tingkat kesopanannya dalam bermedia sosial. Pengamat media sosial Enda Nasution mengatakan survei yang dilakukan DCI Microsoft dapat ditanggapi sebagai peringatan untuk meningkatkan kesadaran dan mendorong interaksi online yang positif. Dengan begitu, ke depan ada gerakan positif untuk memperbaiki bagaimana etika masyarakat bermedia sosial (Fixing the Image of the "Most Rude" Indonesian Netizens World Today News, n.d.). Predikat buruk yang di terima netizen Indonesia perihal bermedia sosial menyiratkan kurang memperhatikan etika dalam penggunaan media sosial. Faktor semakin menyuburkan agresifitas (tindakan tidak beretika) para pengguna di dorong dan di dukung oleh iklim demokrasi yang menjamin kebebasan berbicara dan berpendapat setiap orang di media sosial (Syahputra, 2019, p. 96).

Sejak maraknya penggunaan media sosial di Indonesia dalam sepuluh tahun ini, beberapa kasus menunjukkan bahwa media sosial telah berhasil mengakomodasi partisipasi masyarakat dalam masalah-masalah sosial, politik, ekonomi dan agama (Sokowati, 2019). Di satu sisi, para pengguna media sosial dapat membawa sisi positif yang berdampak di kehidupan nyata, namun di sisi yang lain mereka juga dapat menciptakan tindakan yang merusak kehidupan suatu masyarakat. Hal ini disebabkan ranah publik, manusia tidak bertindak sendiri-sendiri, tetapi bersama. Karena media sosial dunia bersama, maka para penggunanya harus mampu menggerakkan kebersamaan. Di ruang publik ini pula pengguna media sosial mengatur apa yang menjadi kepentingan sebagai kelompok sesama pengguna. Karena kelompok sosial, mereka mengambil peran sosio-ekonomi, sosio-politik dan sosio-kultural yang mampu mempengaruhi kehidupan nyata (Fuchs, 2014, p. 61).

Pada masa kini, media sosial bisa dikatakan sudah menjadi kebutuhan primer bagi siapa saja, karena media sosial dapat menunjang semua aktivitas baik yang bersifat sosial, ekonomi, terlebih ke-agamaan. Sebagaimana yang diutarakan Daniel Zeng, bagi banyak individu, media sosial telah menjadi sumber informasi utama untuk menangani bila kekurangan informasi, kognitif, serta dapat menemukan jawaban atas pertanyaan spesifik, terlebih menemukan peluang yang berharga baik dalam sosial dan ekonomi. Media sosial telah menjadi platform bagi siapa saja untuk berjejaring dan berkontribusi pada semua jenis dialog dengan menunjukkan keahlian dan opini penggunanya (Zeng et al., 2010).

Dengan beragamnya manfaat media sosial bagi masyarakat, tak diimbangi bagaimana etika bermedia sosial itu sendiri diterapkan. Padahal Indonesia di kenal sebagai negara yang religius, namun jika melihat hasil survei yang dilakukan oleh Digital 
Civility Index mengenai rendahnya kesopanan atau perilaku netizen, menandakan nilainilai etika yang berlandaskan agama belum sepenuhnya teraplikasikan. Image Indonesia sebagai negara religius seharusnya tercermin dari perilaku netizen dalam bermedia sosial, karena agama selalu mendorong umatnya berperilaku santun dan beradab. Kesantunan dan adab ini, menandakan kereligiusan seseorang karena mengimplementasikan nilai-nilai agama. Akan tetapi, perilaku netizen yang buruk dalam bermedia sosial seakan tak tampak mengingat Indonesia di kenal sebagai negara yang demokrasi namun tetap berpatokan pada nilai-nilai agama. Pendapat senada dikemukakan oleh Makin, Indonesia sejak awal kemerdekaannya pada pertengahan abad ke-20, telah merumuskan konsepnya sendiri dalam mengadaptasi prinsip-prinsip kebangsaan, namun berpatokan kepada keyakinan agama (Makin, 2018). Seo pun menyatakan, pengaturan agama terhadap negara telah menjadi ciri khas Indonesia walau negara tidak mengikuti sistim negara muslim Arab Saudi, tetapi tidak juga meniru negara Turki yang mayoritas Islam tetapi bersistim sekuler. Peran agama yang kuat dalam menata bangsa ini mengharuskan warganya tidak boleh tidak beragama (Seo, 2012).

Predikat buruk sebagai netizen dengan tingkat kesopanan paling rendah di Asia Tenggara tentu itu mencakup bagi semua pemeluk agama yang diakui oleh negara. Pelabelan itu juga menandakan masih belum teraplikasinya norma-norma etika berlandaskan agama dalam berinteraksi di media sosial. Padahal agama mendesain manusia menjadi mahluk beretika, sebagaimana yang diungkapkan oleh Wahyuni bahwa kehadiraan agama mampu membantu manusia dalam pembentukan moral, perilaku dan psikologis yang baik (Wahyuni, 2017). Nottingham juga menyebutkan paling sedikit tiga fungsi agama, yaitu: pemeliharaan ketertiban masyarakat, fungsi integratif dan fungsi pengukuhan nilai (Nottingham, 1993, p. 97). Oleh sebab itu, pemerintah, pendidik, terlebih para rohaniawan perlu berpartisipasi memperbaiki melalui peran masingmasing pihak. Tulisan ini hendak menyodorkan dalam kerangka ke-akademikan bagaimana prinsip-prinsip etika Kristiani bermedia sosial dengan merujuk Alkitab sebagai panduan dalam penggunaan platform media sosial ini. Makna etika Kristiani yang di maksud pada tulisan ini adalah kajian yang berkaitan dengan moral, tingkah laku manusia dari sudut pandang Kristen berlandaskan biblis. Sifat etika ditentukan oleh paradigma, keyakinan nya ditentukan oleh karkternya, dan itu mendasari mereka melakukan sesuatu (Crooks, 2015, pp. 1-3).

Topik yang berkaitan dengan etika Kristiani dalam bermedia sosial pernah di tulis oleh Mesirawati Waruwu tentang "Peran Pendidikan Etika Kristen dalam Media Sosial di Era Disrupsi". Garis besar dari pembahasan itu, bagaimana pendidikan etika Kristen dalam kaitannya terhadap dampak perkembangan media sosial di era disrupsi (Waruwu et al., 2020). Kemudian ada juga tulisan David Alinurdin tentang "Etika Kristen dan Teknologi Informasi: Sebuah Tinjauan Menurut Perspektif Alkitab." Tulisan itu menyoroti bagaimana aspek-aspek nilai yang memengaruhi pola pikir, sikap dan perilaku pengguna internet dalam pengolahan informasi, otoritas kebenaran, serta identitas pengguna (Alinurdin, 2018). Kebaruan yang ingin ditawarkan dalam tulisan ini adalah bagaimana orang Kristen (netizen) dalam bermedia sosial yang didasarkan pada etika Kristiani 
berlandasan biblis. Kategori media sosial pada tulisan ini merujuk pada yang dikemukakan oleh Hughes yaitu, Flickr, Youtube Facebook, whatsap, Twitter Instagram (Hughes \& Palen, 2012). Ruang lingkup yang akan di bahas pada topik ini adalah media sosial dalam kaitan ke-agamaan dan prinsip etika Kristiani bermedia sosial. Topik ini perlu di tulis dengan tujuan uraian pada artikel ini menjadi lensa bagi pengguna media sosial khususnya netizen yang mendasarkan keyakinannya kepada Alkitab sebagai Kitab Suci.

\section{Metode}

Penelitian adalah proses yang dilakukan secara sistematis, yaitu mendefinisikan tujuan, mengelola data, dan mengkomunikasikan temuan yang terjadi dalam kerangka yang telah ditetapkan dan sesuai dengan pedoman yang ada. Kerangka kerja dan pedoman itu memberi indikasi akan apa yang dimasukkan dalam penelitian, bagaimana melakukan penelitian, dan jenis kesimpulan apa yang mungkin didasarkan pada data yang dikumpulkan (Williams, 2007, p. 65). Metode yang digunakan dalam penulisan atikel ini adalah metode kualitatif deskriftif dengan pendekatan studi kepustakaan. Zaluchu mengemukakan, metode ini dipergunakan untuk penyelidikan kebenaran yang bersifat relatif, teoretis dan menggunakan hermeneutika sebagai langkah untuk mencari makna dan interpretasi (Sonny Eli Zaluchu, 2021, p. 256). Langkah-langkah yang dilakukan dalam penulisan topik ini dengan mencari dan membaca berbagai referensi seperti buku dan jurnal serta portal berita online yang berkaitan pada topik ini. Kemudian mendeskrifsikan dan menguraikan secara komprehensif, setelah itu penulis menarik kesimpulan dengan memaparkan dari sudut pandang etika Kristiani.

\section{Hasil dan Pembahasan}

\section{Media Sosial dan Aktivitas Keagamaan}

Agama pun berkembang secara online, terutama dalam media sosial. Berbagi keyakinan sendiri secara online atau terlibat dengan konten berbasis agama bukanlah hal yang aneh, terutama di Facebook. Kemampuan teknologi media ini membantu memfasilitasi komunikasi massa tentang cita-cita dan aktivitas keagamaan (Brubaker \& Haigh, 2017). Istilah 'media sosial' mengacu pada aplikasi berbasis internet yang memungkinkan orang untuk berkomunikasi dan berbagi sumber daya dan informasi (Dufty \& others, 2012). Data per-Januari 2021, menunjukkan Indonesia memiliki pengguna internet sebanyak 202,6 juta jiwa. Dengan banyaknya pengguna internet tersebut, maka penggunaan media sosial di tanah airpun hampir semua masyarakat memiliki akses dalam bermedia sosial. Diperkirakan penduduk Indonesia yang menggunakan media sosial pada tahun 2017 mencapai 106 juta dari total populasi 262 juta (Supratman, 2018). Di Indonesia sendiri, penggunaan media sosial telah menjadi primadona bagi masyarakat dalam melakukan setiap aktivitas, baik aktivitas ekonomi, pengutarakan opini, termasuk media sosial juga menjadi sarana dalam menyiarkan aktivitas keagamaan. Di tingkat makro, platform media sosial berpotensi untuk memoderasi hubungan antara agama dan pasar. Situs platform itu dikembangkan untuk 
memajukan sejumlah pengajaran berbasis agama, bentuk lain dari adanya penggalangan dana, perjodohan, tentang membeli dan menjual produk termasuk ibadah jarak jauh melalui live streming (Kamarulzaman et al., 2016).

Dari sisi agama, media sosial sendiri sangat membantu penyebaran ajaran agama apapun yang berdampak dapat menambah jumlah kuantitas penganut agama itu sendiri. Misalnya dari kekristenan sendiri, media sosial dapat dipergunakan dalam penginjilan berbasis digital. Dengan melakukan penginjilan berbasis digital, ini dapat menjangkau orang yang tidak terjangkau secara face. Sebagaimana yang diungkapkan oleh Kgatle, penggunaan media sosial bagi aliran gereja-gereja yang menekankan profetik jelas membantu menyebarkan Injil kepada orang-orang yang berbeda. Gereja yang beraliran profetik ini telah sepenuhnya menggunakan teknologi media untuk menyebarkan Injil lebih cepat dengan jangkuan yang lebih luas (Kgatle, 2018).

Media sosial juga sebagai wadah bagi kekristenan dalam menunjukkan kepada publik ritual tata cara ibadah. Terbukti di masa pandemi ini, hampir semua gereja mengadakan ibadah melalui live streming. Ibadah live streming sekaligus menunjukkan kepada masyarakat global, bagaimana model ritual tata cara ibadah dari kekristenan itu sendiri. Bryson menyatakan, covid-19 memaksa semua denominasi gereja untuk bereksperimen dengan bentuk-bentuk baru pemberian layanan. Pengenalan layanan virtual gereja berdampak kepada makin kuatnya dukungan jemaat kepada pendeta serta makin meningkatkan hubungan gereja dan jemaat. Karena itu layanan virtual ibadah gereja disiarkan secara langsung atau di rekam, di edit, dan dikirimkan kepada seluruh jemaat. Karena itu, covid-19 mendorong pergeseran praktik peribadatan sekaligus pembuktian apakah para pendeta, pengurus gereja memiliki kemampuan untuk berinovasi dan berimprovisasi (Bryson et al., 2020).

Media sosial dalam kaitan aktivitas keagamaan juga memberikan sketsa kejelasan mengenai kepercayaan apa yang dianut oleh penggunanya. Hal ini karena media sosial kerap digunakan oleh penggunanya untuk memposting mengenai isi kitab suci, identitas kebudayaan agama maupun ritual ibadah yang dijalankan. Hjarvard sendiri menyatakan di masa kini media telah menjadi sumber informasi yang penting mengenai isu-isu informasi berkaitan keagamaan, dan informasi yang tersaji di media itu dapat berupa pengalaman religius seseorang. Karena itu media telah mengambil alih banyak fungsi budaya dan sosial dari agama-agama yang dilembagakan dan memberikan bimbingan spiritual, moral, serta bagian-bagian ritual agama itu sendiri (Hjarvard, 2011). Keberadaan media sosial telah menjadi kendaraan berbagai agama di seluruh dunia dengan tujuan membrandingkan agama masing-masing kepada masyarakat global. Dengan menjamurnya media sosial, maka menjamur pula berbagai konten agama yang semuanya dapat di lihat di ruang publik. Internet sebagai ruang bebas dan tanpa batas, adalah tempat yang tepat untuk revitalisasi agama. Karena itu, sebagian besar agama tradisional menggunakan internet secara luas bahkan dapat di sebut sebagai "media spiritual" yang dapat membawa penggunanya menemukan pengalaman religius. Dengan meningkatnya penggunaan media sosial telah mengubah cara banyak agama maupun individu dalam beribadah maupun berdakwah (Zviadadze, 2014). 
Media sosial dalam kaitan aktivitas keagamaan juga membuat semua orang menjadi pelaku aktif dalam penyebaran paham keagamaan. Jika sebelum media sosial hadir, paham penyebaran agama disebarkan oleh para pemuka agama itu sendiri maupun lembaga keagamaan. Maka di masa kini, peran seperti itu bukan lagi bertumpu kepada mereka yang dilabeli sebagai pemuka agama atau lembaga berbasis agama. Tetapi, semua orang dapat berperan melakukan hal itu dengan adanya keberadaan media sosial yang dapat diakses oleh siapapun. Itu semua memungkinkan karena platform media sosial saat ini telah menjadi saluran komunikasi yang relevan dengan partisipasi interaktif atau istilahnya sebagai "komunikasi diri massal", yang meningkatkan otonomi subjek dengan mengubahnya menjadi pengirim dan penerima pesan. Karena itu, platform media sosial adalah alat teknologi yang memungkinkan munculnya interaksi sosial yang menyukai pertukaran gagasan, informasi, dan pengetahuan termasuk ideologi keagamaan.

\section{Prinsip -Prinsip Etika Kristiani Bermedia Sosial}

\section{Tidak Melakukan Body Shaming}

Body shaming merupakan sebuah tindakan pemberian komentar yang berunsur negatif mengenai fisik seseorang di media sosial (Fitria \& Febrianti, 2020, p. 12). Sedangkan menurut Sugiati, body shaming penilaian fisik terhadap seseorang yang dilakukan oleh orang lain yang pada umumnya berkonotasi negatif, sehingga orang tersebut akan merasa malu dengan keadaan fisik atau bentuk tubuhnya (Sugiati, 2019, p. 16). Body shaming adalah tindakan mengomentari fisik seorang di media sosial yang narasi komentarnya bersifat mengejek baik secara verbal maupun non-verbal. Body shaming dikategorikan menjadi dua tindakan. Tindakan yang pertama yaitu seseorang mentransmisikan narasi berupa hinaan, ejekan terhadap bentuk, wajah, warna kulit, postur seseorang dengan menggunakan media sosial. Tindakan kedua dengan cara melakukannya secara verbal atau langsung ditujukan kepada seseorang. Di Indonesia, kasus body shaming kerap menimpa siapa saja baik itu mereka publik figur (artis) maupun masyarakat biasa. Kasus body shaming yang viral di tanah air salah satunya terjadi pada bulan Desember 2018, yaitu menimpa pasangan aktor dan aktris Anjasmara dan Dian Nitami. Publik figur itu memperkarakan netizen dengan mengadukan kepada pihak kepolisian karena kasus body shaming yang diarahkan pada Dian Nitami di akun media sosialnya (Fitria \& Febrianti, 2020).

Fenomena body shaming mulai marak terjadi di tanah air sejak tahun 2010 di kala media sosial Instagram berbasis gambar, foto, serta video menjadi platform yang digemari khalayak buat mengomentari tampilan visual sesama penggunanya. Maka tidak heran bila Instagram menjadi media sosial yang sangat banyak digunakan buat melaksanakan tindakan body shaming. Hadirnya berbagai konten media sosial yang di akses dan disalurkan dalam ranah globalisasi, memiliki standar tertentu yang diterapkan pada hampir semua hal misalnya dalam hal fashion atau bahkan kecantikan. Secara umum, seseorang dicap cantik jika bertubuh bagus, tinggi, berkulit putih dan berambut lurus, sedangkan untuk laki-laki di anggap tampan jika bertubuh atletis, tinggi dan berkulit putih. Maraknya penilaian seperti ini karena media sosial membentuk persepsi 
masyarakat mengenai standarisasi kecakapan dan kecantikan dalam lingkungan sosial (Sugiati, 2019). Karena itu, orang yang telah mencapai standar kecantikan di media sosial akan diperlakukan seolah-olah istimewa dari masyarakat, namun bagi orang yang tidak memenuhi standarisasi publik itu akan di cap kurang cantik dan di anggap remeh atau diabaikan oleh pengguna media sosial. Simon menyebutkan, media sosial menyuburkan perilaku social climber yang mengedepankan penampilan atau aksesoris yang dikenakan dalam tubuh dan menjadi sebuah keutamaan (Simon, 2019).

Tanpa disadari, sebagian mereka yang menyatakan diri sebagai orang Kristen terkadang terjebak pada perbuatan body shaming ketika mengutarakan komentarnya di media sosial. Bentuk body shaming yang diperbuat "kenapa tambah gemuk", "kenapa makin kurus", "ihh, kenapa makin hitam", "tidak langsing lagi ya seperti waktu gadis dulu." Ungkapan-ungkapan komentar seperti ini adalah bagian dari tindakan body shaming. Walau mungkin pada awalnya komentar seperti ini hanya bersifat basa-basi atau bercanda, tetapi lama kelamaan akan menjadi serius hingga mengarah pada olokan yang mengakibatkan ketidaknyamanan dari orang yang menjadi objek body shaming tersebut. Mengomentari keadaan fisik seseorang berdampak pada oknum tersebut merasa rendah diri atau malah menjadi tersinggung bahkan sakit hati (Rachmah \& Baharuddin, 2019).

Prinsip etika Kristiani jelas melarang orang percaya melakukan tindakan body shaming dalam berkomunikasi secara langsung maupun di media sosial. Alkitab menulis "Siapa menghina sesamanya, tidak berakal budi, tetapi orang yang pandai, berdiam diri" (Amsal 11:12). Kata menghina dalam bahasa Ibrani di sebut (מָָז (bāz) yang berarti membenci kekurangan sesama (Proverbs 11 Interlinear Bible, n.d.). Dengan melakukan tindakan body shaming kepada seseorang, itu sama saja mengekspresikan rasa kebencian atas seseorang karena tidak sesuai dengan standar atau ekspektasi mengenai sesuatu yang ditetapkan. John J. Pilch sendiri menyebutkan, penghinaan adalah pemberian komentar atau isyarat negatif yang merendahkan tentang siapa kita, apa yang kita pikirkan, atau apa yang kita lakukan. Penghinaan merupakan salah satu bentuk agresi verbal yang melanggar norma budaya kesopanan dalam lingkup kemasyarakatan (Pilch, 2014). Body shaming adalah pelanggaran dalam prinsip etika Kristiani, karena Alkitab menulis tindakan body shaming merupakan ciri orang yang fasik (Amsal 18:3). Jika negara saja mempunyai delik hukum body shaming, terlebih etika Kristiani melarang secara tegas melakukan itu saat berinteraksi di media sosial.

\section{Menghindari Komentar Bernada Rasis}

Rasisme adalah suatu paham yang merasa ras dirinya, ras yang lebih unggul dari pada ras yang lain. Rasisme ini umumnya berhubungan suku, agama, adat. Oleh Shiao, rasisme menurutnya tindakan atau perlakuan diskriminasi yang membuat ketidaksetaraan karena perbedaan suku, agama atau bangsa yang dilakukan oleh seseorang atau kelembagaan (Shiao \& Woody, 2020). Pendapat lain dikemukakan oleh Hoyt Jr, rasisme adalah istilah dimana banyak wacana atau gagasan di semua bidang teori, praktik, kebijakan, khususnya dalam bidang sosial. Konsep rasisme banyak mengandung interpretasi yang beragam dan bertentangan dan digunakan dalam berbagai cara, untuk 
mengemukakan gagasan sekaligus tindakan yang diajarkan atau dipelajari secara sederhana dan lugas (Hoyt Jr, 2012). Berdasarkan makna tersebut, maka rasisme dapat dimaknai sebagai suatu paham yang menganggap suku, adat, budaya atau bangsa lebih unggul dibandingkan yang lain. Gagasan pemahaman ini dipraktekkan ke bidang sosial sehingga menyebabkan adanya perbedaan perlakuan yang mengarah pada diskriminasi.

Dalam tulisannya, Brown menyebutkan ketika masih terjadi masa perbudakan di Amerika, keturunan orang Afrika-Amerika, mereka yang berkulit gelap, perlakuan rasisme di pandang sebagai sebuah kebiasaan oleh mereka yang berkulit putih walau aktif di gereja. Sayangnya mereka (kulit putih) yang merasa beriman kepada Tuhan dan aktif dalam keanggotaan di gereja, tetap tidak mengakui secara jujur sikap rasisme ada di gereja dan tidak ada protes kolektif dari gereja terhadap perbudakan itu. Akan tetapi, gereja tetap menjalankan misinya untuk menobatkan "orang non-Kristen" kepada Kristus tanpa menentang sistem ekonomi yang membutuhkan kerja paksa dan sistim rasial (Brown, 2019).

Di Indonesia sendiri, kasus rasisme masih kerap terjadi baik secara faktual maupun di jagat media sosial. Walau negara menganut semboyan Bhineka Tunggal Ika yang bermakna berbeda-beda namun tetap satu, namun pada praktiknya rasisme masih dijumpai. Menurut Avuan, angka rasisme serta diskriminasi di Indonesia berdasarkan laporan KOMNAS HAM tercatat dari tahun 2011-2018, sedikitnya terdapat 101 kasus. Permasalahan diskriminasi ras serta etnis yang dilaporkan kepada lembaga ini, meliputi pembatasan terhadap pelayanan publik, maraknya politik etnisitas, pembubaran ritual adat, diskriminasi atas hak kepemilikan tanah untuk kelompok minoritas, dan akses ketenagakerjaan yang belum berkeadilan (Rizki \& Djufri, 2021, pp. 20-21). Kasus rasisme yang sampai menyita perhatian publik hingga viral di berbagai pemberitaan media masa yakni kasus mahasiswa Papua yang di diskriminasi oleh oknum masyarakat di pulau Jawa. Peristiwa rasisme yang terjadi dalam kehidupan nyata, menyebabkan merembet dalam media sosial.

Media sosial turut menyuburkan tindakan rasisme melalui komentar para penggunanya. Wujud dari komentar-komentar yang diungkapkan di media sosial bersifat rasisme adalah "dasar cina", "mata sipit", "kafir", dan sebagainya. Komentar yang sifatnya mengejek dan menyindir suku, ritual adat, tindakan yang bersifat rasis. Berkomentar yang sifatnya menjudge atau menyalahkan semua suku atau budaya hanya karena ada kesalahan oknum, juga berkategori rasisme. Prinsip etika Kristiani melarang orang percaya untuk berkomentar dengan mengarah pada rasisme. Karena Alkitab menulis bahwa setiap suku-bangsa yang ada di dunia ini adalah milikNya. Alkitab menulis "Dalam hal ini tidak ada orang Yahudi atau orang Yunani, tidak ada hamba atau orang merdeka, tidak ada laki-laki atau perempuan, karena kamu semua adalah satu di dalam Kristus Yesus" (Galatia 3:28). Ungkapan Rasul Paulus pada ayat ini menandakan bahwa suatu bangsa, suku, atau klan tidak ada lebih unggul dan istimewa di mata Tuhan. Dengan tidak berkomentar rasis di media sosial, sebagai bentuk mengaplikasikan apa yang diperintahkan oleh firman Allah mengamalkan iman dengan tidak memandang muka (Yakobus 2:1). 


\section{Menghindari Perdebatan Teologis}

Bila mengamati media sosial, sebagian orang Kristen kerap menjadikan media sosial sebagai ajang perdebatan teologis. Dampak dari perdebatan teologis ujungujungnya mengarah pada pertengkaran hingga saling memblokir bila salah satu pihak kalah dalam berargumentasi. Berdebat di media sosial apalagi menyangkut masalahmasalah doktrin Alkitab bukanlah tindakan yang bijaksana. Dikatakan "tidak bijaksana" karena mereka yang berdebat pada umumnya masih ber-Tuhan yang sama, ber-Kitab Suci yang sama dan beragama yang sama. Perdebatan teologis yang dilakukan di media sosial dapat menyebabkan oknum tersebut hilang kontrol diri sehingga ujaran kebencian terucap bahkan berpotensi abai pada etika, moral dan attitude. Oleh Syahputra, menyebutkan kemarahan tersebut kemudian menjelma menjadi kerumunan virtual. Kerumunan virtual tersebut pada gilirannya dapat saling memicu dan mendorong produksi ujaran kebencian di media sosial. Ujaran kebencian (hate speech) merupakan bentuk penghinaan (Syahputra, 2017, p. 462).

Paulus menulis dalam suratnya, bahwa "seorang hamba Tuhan tidak boleh bertengkar, tetapi harus ramah terhadap semua orang. Ia harus cakap mengajar, sabar" (2 Timotius 2:24). Pada ayat ini, secara spesifik Paulus mengingatkan mereka yang terpanggil dalam pelayanan, agar menghindari pertengkaran karena mempersoalkan mengenai ajaran yang palsu ataupun tidak (Everett F. Harisson, 2008, p. 893). Dengan semakin menjamurnya berbagai platform media sosial, maka bentuk pertengkaran dan perdebatan itu dituangkan di media sosial akan terlihat. Prinsip etika Kristiani menghimbau agar menghindari perdebatan teologis, karena perdebatan teologis hanya akan menunjukkan tingkat kognitif teologis siapa yang lebih unggul dan mumpuni. Perdebatan teologis yang dilakukan di media sosial dapat mementik arogansi dalam berkomentar, bahkan berpotensi menumbuhkan kesombongan karena menganggap diri superioritas dan meremehkan orang lain. Media sosial sebagai platform komunikasi kecenderungan membuat penggunanya menunjukkan sifat persaingan di ranah sosial di mana sebagian para penggunanya terkadang mengekspresikan sifat tergelap yang bersangkutan dan tak jarang pengguna media sosial bisa jauh lebih mengerikan daripada yang terlihat di kehidupan nyata (D Sedera et al., 2017).

Perdebatan teologis yang dilakukan di media sosial berkecenderungan bermuara pada saling mengejek karena satu sama lain akan mengklaim bahwa argumentasi teologisnya lebih biblika dan ilmiah. Rasul Paulus telah menasehatkan bahwa hamba Tuhan jangan bertengkar, karena pertengkaran hamba Tuhan kerap berasal dari perdebatan teologis apalagi bila menyangkut pemaknaan doktrin Kitab Suci maupun perbedaan aturan gereja. Alkitab menulis "Ingatkanlah dan pesankanlah semuanya itu dengan sungguh-sungguh kepada mereka di hadapan Allah, agar jangan mereka bersilat kata, karena hal itu sama sekali tidak berguna, malah mengacaukan orang yang mendengarnya" (2 Timotius 2:14). Bersilat kata merupakan satu kata di dalam bahasa Yunani kata benda yang diartikan "berdebat kusir" dan yang diperdebatkan itu seputar ajaran (Everett F. Harisson, 2008, p. 891). Alkitab Terjemahan Firman Allah Yang Hidup 
menulis ayat ini "Ingatkanlah orang-orangmu akan kenyataan-kenyataan ini, dan perintahkanlah mereka dalam nama Tuhan supaya tidak berdebat tentang hal-hal yang tidak penting. Perdebatan semacam itu membingungkan dan tidak berfaedah, malah merugikan" (2 Timotius 2:14 Terjemahan FAYH). Perdebatan teologis yang dilakukan di media sosial merupakan tidaklah terpuji karena dalam etika Kristiani tidak etis.

\section{Tidak Mengumbar Hal Negatif}

Prinsip etika Kristiani berikutnya dalam bermedia sosial adalah tidak mengumbar hal negatif. Yang dimaksud tidak mengumbar hal negatif adalah tidak mempublish masalah yang sifatnya pribadi. Bentuk dari masalah pribadi itu seperti: permasalahan keluarga, pernikahan, suami/istri, pekerjaan, dan sebagainya. Tidak mengumbar hal negatif juga bermakna tidak memosting aib orang lain untuk dikonsumsi khalayak umum. Di era media sosial sekarang, memang memungkinkan siapa saja dapat meilihat aktivitas apa yang sedang dilakukan oleh penggunanya. Media sosial membuat ruang privasi seseorang dapat di lihat oleh sesama pengguna. Walau media sosial menjadi ruang publik, orang Kristen hendaknya mempunyai batasan-batasan apa yang perlu dibagikan dan diperlihatkan untuk konsumsi khalayak umum agar apa yang di publish tidak merusak jati dirinya. Bagaimanapun juga, dunia maya adalah dunia yang bisa dicopy, diedit, dihack, dan dipalsukan. Sehebat-hebatnya berinteraksi dan bermain di dunia maya digital, tetaplah yang asli adalah dunia nyata. Telepon pintar adalah alat pendukung berkomunikasi di dunia maya digital, seharusnya tidak boleh menggantikan komunikasi di dunia nyata, apalagi dalam konteks bergereja, berkomunitas Kristen dan berkeluarga (Hay, 2015, p. 57).

Moral yang diajarkan dan dipraktikkan oleh leluhur bangsa, demikian juga yang diajarkan oleh agama, perlahan seakan memudar dalam kehidupan keseharian masyarakat tanah air. Penyebabnya, karena ruang-ruang privat, bahkan publik sekalipun dipenuhi oleh hasrat buas, ujaran kebencian, mengumbar keseronokan, mematikan karakter orang lain, minus etika, itulah kata yang tepat untuk mengungkapkan realitas kekinian bila di lihat dari media sosial. Alkitab memberi panduan sebagai orang percaya, hal apa yang pantas untuk diperlihatkan di ruang publik, dan dengan menampilkan kepantasan di ruang publik, memperlihatkan norma-norma Kristiani berlandaskan Alkitab teraplikasikan dalam bermedia sosial. Teks ayat Alkitab yang tertulis berikut dapat dijadikan sebagai pegangan untuk tidak mengumbar hal negatif di ruang publik baik di dunia nyata terutama di dunia maya. "Siapa mengumpat, membuka rahasia, sebab itu janganlah engkau bergaul dengan orang yang bocor mulut" (Amsal 20:19). Mengumbar hal negatif di media sosial dapat dikategorikan juga sebagai orang yang bocor mulut. Darusman mengemukakan, bersamaan dengan era yang serba modern ini, banyak ditemukan nyinyiran, hinaan, cacian, dan makian tersebar di media sosial. Padahal konsekuensi dari perbuatan itu dapat menyebabkan konflik panjang antara pelaku dan korban. Padahal komentar yang bersifat mengejek jelas- jelas dilarang agama, malah hal itu dipamerkan di media sosial. Mereka yang kerap mengejek adalah para tokoh politik, ekonomi terlebih tokoh agama. Secara perlahan fenomena perilaku bermedia sosial 
seperti ini mulai memudarkan toleransi dan persaudaraan sesama anak bangsa (Darusman et al., 2021).

\section{Implikasi}

Ide gagasan pokok dari tulisan ini karena adanya data faktual yang disajikan oleh Digital Civility Index (DCI) tentang rendahnya tingkat kesopanan (etika) netizen tanah air dalam menggunakan media sosial. Implikasi teoritis dari tulisan ini, pendidik agama Kristen dapat menjadikan topik ini untuk diajarkan dalam kelas-kelas keagamaan baik di sekolah maupun di gereja, untuk disampaikan kepada para remaja yang mendominasi dalam penggunaan media sosial di tanah air. Sementara praksisnya, para gembala sidang dapat mengutarakan gagasan pada artikel ini melalui khotbah di ibadah raya.

\section{Rekomendasi Untuk Penelitian Lanjutan}

Topik penelitian ini dapat dilanjutkan dengan menggali bagaimana penggunaan media dapat mempengaruhi psikologi penggunanya dalam kaitan agama. Dapat juga diteliti, penggunaan media sosial dalam kaitan sosiologi yang dielaborasikan dengan antropologi.

\section{Kesimpulan}

Tingkat kesopanan netizen tanah air dalam bermedia sosial merupakan terburuk untuk skala di Asia Tenggara. Pelabelan itu mengisyaratkan kurangnya etika berlandaskan agama teraplikasikan dalam penggunaan media sosial. Media sosial sudah menjadi kebutuhan yang primer untuk saat ini karena platform jejaring sosial ini menawarkan segala kemudahan dalam berkomunikasi, kebermanfaatan dalam menjalankan bisnis atau pekerjaan, terlebih kebermanfaatan dalam aktivitas keagamaan. Besarnya manfaat media sosial di masa kini harus diimbangi bagaimana beretika menggunakan situs media online ini. Prinsip etika Kristiani menekankan ketika bermedia sosial tidak melakukan body shaming, karena hal itu adalah tindakan penghinaan atau pengejekan fisik yang dilakukan kepada seseorang. Tidak berkomentar rasis, tidak melakukan perdebatan teologis, serta tidak mempublish aib adalah hal yang perlu dihindari karena secara etika Kristiani melarangnya. Dengan tidak melakukan hal itu, kita dapat menggunakan media sosial sebagai wadah pengembangan diri sekaligus memuliakan Tuhan melalui aktivitas keagamaan.

\section{Rujukan}

Alinurdin, D. (2018). Etika Kristen Dan Teknologi Informasi: Sebuah Tinjauan Menurut Perspektif Alkitab. Veritas: Jurnal Teologi Dan Pelayanan, 17(2), 91-105.

Brown, A. W. (2019). Racism and the Christian church in America: Caught between the knowledge of good and evil. Social Work in Public Health, 34(1), 134-144.

Brubaker, P. J., \& Haigh, M. M. (2017). The religious Facebook experience: Uses and gratifications of faith-based content. Social Media+ Society, 3(2), 2056305117703723. 
Bryson, J. R., Andres, L., \& Davies, A. (2020). COVID-19, virtual church services and a new temporary geography of home. Tijdschrift Voor Economische En Sociale Geografie, 111(3), 360-372.

Crooks, R. H. (2015). An introduction to Christian ethics. Routledge.

D Sedera, D., Lokuge, S., \& Chandrasekara, D. (2017). Human Degradation with the Use of Social Media: A Theological Perspective.

Darusman, Y. M., Bastianon, B., Susanto, S., Benazir, D. M., \& Setiawan, T. (2021). Pentingnya Pemahaman Tentang Kemanfaatan Dan Kemudaratan Media Sosial. Abdi Laksana: Jurnal Pengabdian Kepada Masyarakat, 2(1), 173-179.

Dufty, N., \& others. (2012). Using social media to build community disaster resilience. The Australian Journal of Emergency Management, 27(1), 40-45.

Everett F. Harisson. (2008). The Wycleffe Bible Commentary (Charles F. Pfeiffer (Ed.); 3rd ed.). Gandum Mas.

Fitria, K., \& Febrianti, Y. (2020). The Interpretation And Attitude Of Body Shaming Behavior On Social Media (A Digital Ethnography Study On Instagram). Diakom: Jurnal Media Dan Komunikasi, 3(1), 12-25.

Fixing the Image of the "Most Rude" Indonesian Netizens - World Today News. (n.d.). Retrieved March 25, 2021, from https://www.world-today-news.com/fixingthe-image-of-the-most-rude-indonesian-

Fuchs, C. (2014). Social media and the public sphere. TripleC: Communication, Capitalism \& Critique. Open Access Journal for a Global Sustainable Information Society, 12(1), 57-101.

Hay, A. W. (2015). Gaya Hidup Digital Kristiani Era Globalisasi. Jurnal Youth Ministry, 3(1), 51-59.

Hjarvard, S. (2011). The mediatisation of religion: Theorising religion, media and social change. Culture and Religion, 12(02), 119-135.

Hoyt Jr, C. (2012). The pedagogy of the meaning of racism: Reconciling a discordant discourse. Social Work, 57(3), 225-234.

Hughes, A. L., \& Palen, L. (2012). The evolving role of the public information officer: An examination of social media in emergency management. Journal of Homeland Security and Emergency Management, 9(1).

Kamarulzaman, Y., Veeck, A., Mumuni, A. G., Luqmani, M., \& Quraeshi, Z. A. (2016). Religion, markets, and digital media: Seeking halal food in the US. Journal of Macromarketing, 36(4), 400-411.

Kgatle, M. S. (2018). Social media and religion: Missiological perspective on the link between Facebook and the emergence of prophetic churches in southern Africa. Verbum et Ecclesia, 39(1), 1-6.

Makin, A. (2018). 'Not a Religious State' A study of three Indonesian religious leaders on the relation of state and religion. Indonesia and the Malay World, 46(135), 95116.

Nottingham, E. K. (1993). Agama dan Masyarakat: Suatu Pengantar Sosiologi. Jakarta: Rajawali Press. 
Pilch, J. J. (2014). Insults and face work in the Bible. HTS Theological Studies, 70(1), 1-8. Proverbs 11 Interlinear Bible. (n.d.). Retrieved April 1, 2021, from https://biblehub.com/interlinear/proverbs/11.htm

Rachmah, E., \& Baharuddin, F. (2019). Faktor Pembentuk Perilaku Body Shaming Di Media Sosial. Prosiding Seminar Nasional \& Call Paper Psikologi Sosial, 66-73.

Rizki, A. M., \& Djufri, R. A. (2021). Pengaruh Efektivitas Pembelajaran Bhineka Tunggal Ika Terhadap Angka Rasisme Dan Diskriminasi Di Indonesia 2019. Vidya Samhita: Jurnal Penelitian Agama, 6(1).

Seo, M. (2012). Defining 'religious' in Indonesia: toward neither an Islamic nor a secular state. Citizenship Studies, 16(8), 1045-1058.

Shiao, J., \& Woody, A. (2020). The Meaning of "Racism." Sociological Perspectives, 0731121420964239.

Simon, S. (2019). Fenomena Sosial Climber Ditinjau Dari Perspektif Etika Kristen. Fidei: Jurnal Teologi Sistematika Dan Praktika, 2(2), 303-324.

Sokowati, M. E. (2019). Questioning Public Participation in Social Media Activities in Indonesia. Komunikator, 11(2), 116-124.

Sonny Eli Zaluchu. (2021). Metode Penelitian di dalam Manuskrip Jurnal Ilmiah Keagamaan. Teologi Berita Hidup, 3(2).

Sugiati, T. (2019). The influence of body shaming toward FISIP Airlangga University students behaviour pattern. Indonesian Journal of Social Sciences Volume, 11(02), 16-24.

Supratman, L. P. (2018). Penggunaan media sosial oleh digital native.

Syahputra, I. (2017). Demokrasi virtual dan perang siber di media sosial: Perspektif Netizen Indonesia. Jurnal Aspikom, 3(3), 457-475.

Syahputra, I. (2019). Expressions of hatred and the formation of spiral of anxiety on social media in Indonesia. SEARCH Journal of Media and Communication Research, 11(1), 95-112.

Wahyuni, D. (2017). Agama Sebagai Media dan Media Sebagai Agama. Jurnal Ilmu Agama: Mengkaji Doktrin, Pemikiran, Dan Fenomena Agama, 18(2).

Waruwu, M., Arifianto, Y. A., \& Suseno, A. (2020). Peran Pendidikan Etika Kristen dalam Media Sosial di Era Disrupsi. JUPAK: Jurnal Pendidikan Agama Kristen, 1(1), 3846.

Williams, C. (2007). Research methods. Journal of Business \& Economics Research (JBER), $5(3)$.

Zeng, D., Chen, H., Lusch, R., \& Li, S.-H. (2010). Social media analytics and intelligence. IEEE Intelligent Systems, 25(6), 13-16.

Zviadadze, S. (2014). I 'like'my Patriarch. Religion on Facebook. New Forms of Religiosity in Contemporary Georgia. Online-Heidelberg Journal of Religions on the Internet, 6. 